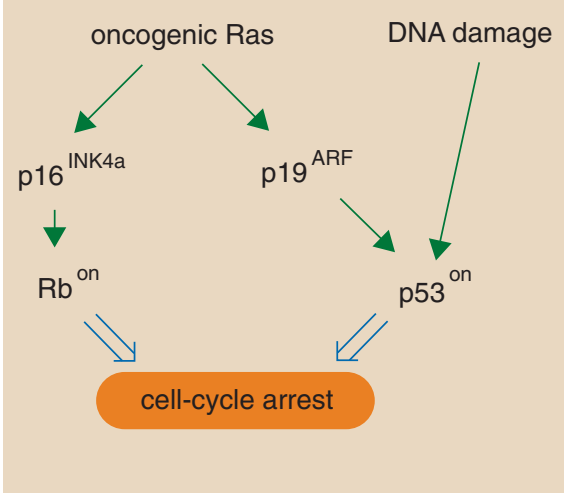

Figure 2 Anti-tumorigenic responses mediated by the products of the INK4a-ARF locus. Rb, retinoblastoma.

a peptide containing a functional p19 $9^{\text {ARF }}$ domain. It has previously been reported that $(I N K 4 a-A R F)^{\Delta 2,3}$ cells do not arrest when oncogenic Ras is introduced but are still able to induce p53 (ref. 2). In the light of our present results, this suggests that $(I N K 4 a-A R F)^{\Delta 2,3}$ cells retain a functional, or partly functional, $A R F$ gene. Taken together, these data indicate that oncogenic Ras elicits an anti-tumorigenic response mediated by the upregulation of both $\mathrm{p} 19^{\mathrm{ARF}}$ and p16 ${ }^{\text {INK4a }}$, which in turn activate the tumour suppressors p53 and retinoblastoma, respectively (Fig. 2).

Other oncogenes that are mechanistically unrelated to Ras have recently been reported to activate p53 in a p19 $9^{\mathrm{ARF}_{-}}$ dependent manner, resulting in a proapoptotic state ${ }^{11,12}$. We speculate that $\mathrm{p} 19^{\mathrm{ARF}}$ senses unscheduled entry into the $\mathrm{S}$ phase of the cell cycle. Homozygous loss of the INK $4 a-A R F$ locus is common in human tumours. The results reported here, together with those of previous reports ${ }^{2,6,11,12}$, indicate that the loss of $\mathrm{p} 19^{\mathrm{ARF}}$ and $\mathrm{p} 16^{\mathrm{INK} 4 \mathrm{a}}$ renders cells unprotected against the action of oncogenes.

Ignacio Palmero,

Cristina Pantoja,

Manuel Serrano

Department of Immunology and Oncology,

Centro Nacional de Biotecnología,

CSIC, Campus de Cantoblanco,

Madrid E-28049,

Spain

e-mail:mserrano@cnb.uam.es

1. Weinberg, R. A. Cell 88, 573-575 (1997).

2. Serrano, M., Lin, A. W., McCurrach, M. E., Beach, D. \& Lowe, S. W. Cell 88, 593-602 (1997).

3. Pomerantz, J. et al. Cell 92, 713-723 (1998).

4. Zhang, Y., Xiong, Y. \& Yarbrough, W. G. Cell 92, 725-734 (1998).

5. Kamijo, T. et al. Proc. Natl Acad. Sci. USA 95, 8292-8297 (1998).

6. Kamijo, T. et al. Cell 91, 649-659 (1997).

7. Levine, A. J. Cell 88, 323-331 (1997).

8. Haber, D. A. Cell 91, 555-558 (1997)

9. Serrano, M. et al. Cell 85, 27-37 (1996).

10. Quelle, D. E., Cheng, M., Ashmun, R. A. \& Sherr, C. J. Proc. Natl Acad. Sci. USA 94, 669-673 (1997).

11.Zindy, F. et al. Genes Dev. 12, 2424-2433 (1998).

12. de Stanchina, E. et al. Genes Dev. 12, 2434-2442 (1998).

\section{Impacts on Earth in the Late Triassic}

Spray et al. ${ }^{1}$ postulate that five widely dispersed terrestrial impact structures with very similar geological age estimates (about 214 million years ago, in the Late Triassic epoch) are evidence of a multiple impact event. Most notably, the three largest impact structures, Saint Martin in western Canada ( 40 km diameter), Manicouagan in eastern Canada ( $\sim 100 \mathrm{~km}$ diameter), and Rochechouart in France $(\sim 25 \mathrm{~km}$ diameter), plot at virtually the same palaeolatitude in a continental reconstruction. Spray et al. suggest that this apparent crater chain was produced within hours as a series of coaxial projectiles collided in rapid succession with the rotating planet Earth, and drew analogies to the recent collision sequence of fragmented comet ShoemakerLevy 9 with Jupiter.

However, published palaeomagnetic data for the Manicouagan ${ }^{2,3}$ and Rochechouart $^{4}$ impact structures argue strongly against such a closely timed origin for these ancient events. This is because the characteristic remanent magnetizations of the melt rocks, including the most rapidly cooled glassy phases, indicate formation in a Late Triassic palaeomagnetic dipolar field of normal polarity at Manicouagan but of reverse polarity at Rochechouart.

These impact events must therefore have been separated temporally by at least the few thousand years ${ }^{5}$ it takes for a geomagnetic polarity reversal to take place, a process which in any case occurred relatively infrequently (at an average rate of about twice per million years ${ }^{6,7}$ ) in the Late Triassic. Thus, although there is an interesting concentration of impact events in the Late Triassic, the opposite geomagnetic polarities recorded by the Manicouagan and Rochechouart melt rocks appear to preclude a synchronous multiple impact origin.

Dennis V. Kent

Lamont-Doherty Earth Observatory,

Columbia University,

Palisades, New York 10964, USA

1. Spray, J. G., Kelley, S. P. \& Rowley, D. B. Nature 392, 171-173 (1998).

2. Robertson, W. A. Can. J. Earth Sci. 4, 641-649 (1967).

3. Larochelle, A. \& Currie, K. L. J. Geophys. Res. 72, 4163-4169 (1967).

4. Pohl, J. \& Soffel, H. Z. Geophysik 37, 857-866 (1971).

5. Clement, B. M. \& Kent, D. V. Nature 310, 488-491 (1984).

6. Gallet, Y., Besse, J., Krystyn, L., Theveniaut, H. \& Marcoux, J. Earth Planet. Sci. Lett. 117, 443-456 (1993).

7. Kent, D. V., Olsen, P. E. \& Witte, W. K. J. Geophys. Res. 100, 14965-14998 (1995).

Spray replies - Kent raises an interesting point regarding the proposed late Triassic multiple-impact event ${ }^{1}$. It might appear contradictory that the Manicouagan ( 100 $\mathrm{km}$ diameter) and Rochechouart ( $25 \mathrm{~km}$ diameter) impact structures possess normal and reversed geomagnetic reversals, respectively, if they were formed within hours of each other, as we suggested ${ }^{1}$. However, palaeomagnetic fields are acquired when magnetic mineral phases pass through their Curie points (the temperatures at which iron minerals assume magnetic order and remain with their magnetic moments parallel to the Earth's magnetic field at that time). Critically, this does not necessarily coincide with the time of formation of the host rocks.

Rochechouart possesses a thin, sporadically developed impact melt layer $(4 \mathrm{~m}$ thick at most). The palaeomagnetic data of Pohl and Soffel ${ }^{2}$ were obtained from glassbearing impact breccias and lithic breccias. The high-clast/low-melt content would have resulted in these rocks cooling below their Curie points (for example, approximately $580^{\circ} \mathrm{C}$ for pure magnetite) within a short geological period, probably less than 100 years. This would be due to the cooling effect of the entrained cold clasts and the relatively rapid conductive and convective cooling of such a thin melt layer.

In contrast, Manicouagan, as a much larger impact structure, possesses an extensive and significantly thicker melt sheet (>230 $\mathrm{m}$ and probably $500 \mathrm{~m}$ in total original thickness). Glass-rich breccias were not sampled as part of palaeomagnetic studies at Manicouagan ${ }^{4,5}$, but crystalline melt sheet was sampled and many of the samples were medium-grained. It would have taken thousands, perhaps tens of thousands, of years for such a body of superheated melt to cool below the relevant Curie points. For example, Onorato et al. ${ }^{3}$ calculate that it would have required about 1,600 years for the centre of the melt sheet to reach its solidus $\left(915^{\circ} \mathrm{C}\right)$ and up to 10,000 years to cool to about $600^{\circ} \mathrm{C}$. This is for a body estimated at $200 \mathrm{~m}$ thick. We know now that $500 \mathrm{~m}$ is a more realistic thickness, so the estimates $^{3}$ are on the low side.

Consequently, although both Manicouagan and Rochechouart could have been formed within hours of each other, the resulting impact-generated rocks would have reached their Curie points at times sufficiently different to allow for a natural geomagnetic reversal to have taken place, accounting for the different magnetic polarities of these impact structures.

John G. Spray

Department of Geology,

University of New Brunswick,

Fredericton, New Brunswick E3B 5A3, Canada

1. Spray, J. G., Kelley, S. P. \& Rowley, D. B. Nature 392, 171-173 (1998).

2. Pohl, J. \& Soffel, H. Z. Geophys. 37, 857-866 (1971).

3. Onorato, P. I. K., Uhlmann, D. R. \& Simonds, C. H. J. Geophys. Res. 83, 2789-2798 (1978)

4. Robertson, W. A. Can. J. Earth Sci. 4, 641-649 (1967).

5. Larochelle, A. \& Currie, K. L. H. J. Geophys. Res. 72, 4163-4169 (1967). 